\title{
Growing pains: \\ the Asia Pacific Refugee Rights Network at seven years
}

\author{
Savitri Taylor \\ La Trobe University
}

\begin{abstract}
The mission of the Asia Pacific Refugee Rights Network (APRRN), as stated in its Constitution, is 'to advance the rights of refugees and other people in need of protection in the Asia Pacific region'. This article describes and analyses APRRN's internal governance and resourcing and the manner in which it is going about achieving its mission. It argues that APRRN's organisational strength is inadequate to support all that it is trying to do. The article concludes by considering what APRRN could do to improve the likelihood of achieving success in the pursuit of its mission and reflecting on the lessons of the APRRN case study for wider civil society.
\end{abstract}

\section{Introduction}

In November 2008, at a meeting in Kuala Lumpur hosted by FORUM-ASIA, the representatives of 70 civil society organisations (CSOs) from 14 countries decided to establish the Asia Pacific Refugee Rights Network (APRRN) (APRRN 2009, p. 6; International Detention Coalition (IDC) 2008). APRRN membership is open to CSOs and individuals anywhere in the world that subscribe to its core principles and agree to abide by its governance rules (APRRN Constitution 2014, art. 2.1) ${ }^{1}$. By November 2015, APRRN had 249 members across 26 countries (APRRN Secretariat, email, 8 November 2015). Of these, 135 (54 per cent) were organisational members (APRRN Secretariat, email, 8 November 2015). The rest were individual members.

\footnotetext{
${ }^{1}$ For membership purposes, APRRN's definition of civil society excludes 'governmental, inter-governmental, para-governmental and para-military bodies; national human rights institutions; and ... the media' and also the employees of such organisations (APRRN Constitution 2014, art. 2.1(2)).

Savitri Taylor, La Trobe Law School, La Trobe University, Melbourne. Email: s.taylor@latrobe.edu.au ISSN: 1837-5391; https://epress.lib.uts.edu.au/journals/index.php/mcs CCS Journal is published under the auspices of UTSePress, Sydney, Australia (C) 2016 Savitri Taylor. This is an Open Access article distributed under the terms of the Creative Commons Attribution 4.0 Unported (CC BY 4.0) License (https://creativecommons.org/licenses/by/4.0/), allowing third parties to copy and redistribute the material in any medium or format and to remix, transform, and build upon the material for any purpose, even commercially, provided the original work is properly cited and states its license.
} 
APRRN's mission, as stated in its Constitution (2014 art.1.1), is 'to advance the rights of refugees and other people in need of protection ${ }^{2}$ in the Asia Pacific region' ${ }^{3}$. APRRN endeavours to achieve its mission through three categories of activities which it refers to as its ‘core pillars'. These are, again using APRRN terminology, 'outreach and sharing of knowledge and resources'; ‘mutual capacity strengthening'; and 'joint advocacy’ (APRRN Constitution 2014, art. 1.1).

APRRN is best classified as a 'network organisation'. In other words, it is a hybrid 'combining elements of formality with those elements from a loose network structure' (Diani 2011, p. 226). My purpose in this article is to consider whether APRRN is, or could be, a successful organisation of its type. The fact that APRRN continues to exist means, of course, that it has so far succeeded in surviving, which is no small achievement (Ashman \& Sugawara 2013, p. 397). However, the kind of success I mean is success in achieving APRRN's mission. This article describes and analyses APRRN's organisational structure and resourcing and the manner in which it is going about achieving its mission. It also considers whether APRRN's organisational strength is adequate to support all that it is trying to do. It concludes by reflecting on the implications of the findings both for APRRN and for wider civil society.

\section{Methodology}

As well as being an academic, I have been an individual member of APRRN since December 2008. As a member of APRRN I have access to information that is confidential to the network. For example, I am included in APRRN's members only Google group email list and through that list I receive copies of documents which are not shared with outsiders, such as Steering Committee minutes. More generally, my inclusion in the members-only email list and my participation since 2008 in various meetings and informal conversations among members have made me privy to governance, strategic and other discussions which would not be conducted in the presence of outsiders. In order to avoid breaching confidentiality, I have

\footnotetext{
${ }^{2}$ APRRN's definition of 'people in need of protection' is very broad. 'It includes: refugees, asylum seekers, torture survivors and complainants, trafficked persons, internally displaced persons (IDPs), stateless persons and returnees. It includes people displaced by conflict, persecution and other forms of human rights abuse, and stateless persons in situ, who are in need of protection (but not in all cases international protection)' (APRRN 2014a)

${ }^{3}$ APRRN's definition of the Asia Pacific region is also very broad, being the same as the definition used by the Office of the United Nations High Commissioner for Refugees (UNHCR) (UNHCR 2015a)
} 
chosen to include in this article only information which could be accessed by any member of the public. However, this article is written from an 'insider position' with all of the strengths and weaknesses that entails (Uldam \& McCurdy 2013). On the side of strength, the article benefits from the insights I have gained through a long period of participant observation as a trusted insider. For example, I am less likely than outsiders to have misinterpreted or been misled by the content of APRRN's publicly available documents because I am aware also of what has been omitted from them (Lichterman 1998; Labaree 2002). On the side of weakness, my membership of APRRN compromises my objectivity. I keep faith with the reader by being open about the latter fact. Other scholars have grappled with the same dilemma and arrived at the same solution (Labaree 2002; Pulido 2008; Heyman 2011; Uldam \& McCurdy 2013).

\section{Background}

At the end of 2014, the Asia Pacific region hosted around 117,000 asylum seekers and 3.8 million refugees (UNHCR 2015b, Table 1). Humanitarian considerations result in most countries in the Asia Pacific tolerating the unauthorised presence of asylum seekers and refugees within their borders most of the time. However, less than half of the countries in the Asia-Pacific are parties to the 1951 Convention relating to the Status of Refugees or its 1967 Protocol; fewer still have a domestic legal framework for determining asylum seekers’ protection claims or protecting refugees. None are willing to provide refugees with a durable solution to their plight in the form of location integration.

Without legal status in their host countries, asylum seekers and refugees in the Asia Pacific region live in fear of being detained and/or returned to the dangers of their home country. Most do not have adequate access to the necessities of life. Some suffer mistreatment at the hands of local authorities and/or communities. UNHCR does its best to provide protection to those falling within its mandate, but the total funds it has available fall far short of its needsbased budget for the region (UNHCR 2015c, p. 195). In any event, the UNHCR cannot protect asylum seekers and refugees from host-country governments or provide them with durable solutions; all it can do is advocate on behalf of asylum seekers and refugees with governments. 
Unsurprisingly, some of those who find conditions intolerable where they are decide to take matters into their own hands and move on in an irregular manner. Australia is often a target destination for these irregular onward movers, the most visible of whom travel by boat. Unfortunately, Australia and other regional countries have chosen to focus not on the human insecurity which motivates irregular movement but on the challenge to sovereign authority represented by it. Since it took office in September 2013, Australia’s present Liberal-National Coalition government has displayed a particularly single minded focus on deterrence. As well as continuing the previous Labor government's deterrence strategies, the Coalition government is turning back boats to their most recent country of departure (usually Indonesia but sometimes countries of origin). It has also sought to achieve a 'regional deterrence framework' (Coalition 2013) through fora such as the Bali Process ${ }^{4}$ and bilateral engagement with regional countries.

Despite the lack of positive leadership from Australia, there is hope. In many regional countries, CSOs are attempting to fill the protection gap through service provision, advocacy, or both. Unlike the UNHCR, or, for that matter, Australia, which may be perceived as trying to impose an external agenda on a country against its national interest, locally-based CSOs have local legitimacy because they act and speak for local constituencies. Their pro-refugee views may not currently be held by a majority in their society but they are better placed than outsiders to achieve better protection - perhaps even local integration - for refugees over time. The question I address in this article is whether APRRN is, or could be, a vehicle which enables these CSOs to achieve more together than they could individually.

Since this article is appearing in a special issue of Cosmopolitan Civil Societies Journal that focuses on the regional impacts of Australian asylum seeker policy, I expect its primary audience to be those interested in refugee policy. However, I hope the article will also be of interest to a wider audience interested in civil society but not necessarily in refugee policy. There is now a large volume of academic literature which focuses on civil society, both national and transnational (Anheier 2014). However, much of the literature dealing with the transnationalisation of civil society focuses on the global rather than the regional level

\footnotetext{
${ }^{4}$ The Bali Process on People Smuggling, Trafficking in Persons and Related Transnational Crime is an Asia Pacific regional forum which was inaugurated in 2002. Forty-five countries, along with UNHCR, the International Organization for Migration and the United Nations Office on Drugs and Crime, are members of the forum which operates through Ministerial Conferences and working groups of senior government officials to achieve practical cooperation on the issues to which its name makes reference.
} 
(Godsäter 2015, p. 101). This article adds to the literature on regional civil society by providing an in-depth case study of a particular regional civil society network. Further, it does so in a way which also makes a contribution to another emergent body of literature. As was observed in the introduction to a recent special issue of Voluntas, most of the literature on civil society is bifurcated, dealing either with the role that civil society organisations and networks play in transnational governance or with the internal governance of transnational civil society organisations and networks (Steen-Johnsen, Eynaud, \& Wijkström 2011, pp. 555-556). However, as that introduction went on to emphasise, it is worth analysing the internal and external aspects of governance together because 'these dimensions of governance are closely intertwined: the internal governance game shapes the conditions for the organization's positions and actions in the external governance environment, and vice versa'. (Steen-Johnsen, Eynaud \& Wijkström 2011, p. 556). The articles in the special issue in question focused on the impacts of the external governance environment on internal governance. This article, by contrast, follows Wong (2012) in focusing on the reverse, i.e. the impacts of internal governance on a civil society organisation's ability to engage with the external governance environment.

\section{APRRN's 'Enabling Foundation'5}

APRRN's organisational membership is diverse. The majority of members are purely national organisations (APRRN Secretariat, email, 26 August 2015), but some are national offices of international CSOs, or are themselves transnational network organisations. About 60 per cent of APRRN's organisational members are involved in direct delivery of legal, health, education and/or other social services, while the remainder are primarily engaged in research, capacity building and/or advocacy.

Though APRRN is dedicated to advancing the rights of 'people in need of protection', only about 40 per cent of the organisational members focus on people in need of protection and of these a negligible number are organisations of people in need of protection. The other 60 per cent are development organisations, human rights organisations, children’s rights organisations, migrant rights organisations, and so on.

\footnotetext{
${ }^{5}$ This is the terminology used in APRRN's Strategic Plan 2014-2018.
} 
Such a large and diverse membership is a strength in as much as it enables the harnessing together of a wide range of contacts, ideas, expertise, perspectives and skills for the purpose of achieving the organisation's mission (Center for Victims of Torture 2004, p. 118). For example, by including development organisations, human rights organisations and others in its membership, APRRN obtains access to the expertise necessary to frame refugee protection issues as also being development issues, human rights issues and so on, thus improving the likelihood of obtaining social and political traction for refugee protection issues (Murdie 2014, pp. 314-315; Nash 2014, pp. 216-217). However, diversity can also be a problem. The greater the diversity, the more likely it is that different members will have incompatible ideas about what success would look like if achieved (Katz \& Anheier 2005). Even if members have a truly common vision, the greater the diversity of network members, the greater the potential for disagreement over priorities and strategies on the road to achieving that vision. At the same time, the larger the membership the less likely that disagreements can be resolved in informal ways which depend on personal relationships of trust and friendship. Thus far, APRRN has been able to meet this challenge because it has had fairly formalised governance arrangements from the outset.

APRRN's Constitution sets out the main rules relating to accountability and decision making ${ }^{6}$. APRRN's General Assembly, which is composed of its organisational members, is described in its Constitution (2014, art. 4) as its 'highest policy making body'. It meets every two years to make decisions about the network's activities and governance. The most recent meeting at the time of writing was held in Bangkok in September 2014. At this meeting, the General Assembly adopted a strategic plan for the period 2014-2018.

APRRN has four geographic working groups: East Asia, South Asia, South East Asia, and Australia, New Zealand \& the Pacific. It also has five thematic working groups: Legal Aid \& Advocacy, Immigration Detention, Women \& Girls at Risk, Right to Health, and Statelessness ${ }^{7}$. Each APRRN member automatically becomes a member of a sub-regional working group according to their geographic location and can also become a member of one or more thematic working groups according to their particular interests. At each General

\footnotetext{
${ }^{6}$ APRRN's Constitution replaced its original Articles of Association.

${ }^{7}$ With the exception of the statelessness working group, which was formally established by the APRRN General Assembly in 2012, all the working groups were established at the time APRRN itself was established. A separate International Advocacy Working Group which was established at that time ceased to exist after the 2010 General Assembly meeting.
} 
Assembly meeting, the organisational members of each working group elect a Chair and a Deputy Chair from within their ranks for a two year term and develop an action plan for themselves which aligns with the strategic plan of the network as a whole (APRRN Constitution 2014, art. 6) ${ }^{8}$.

The chairs and deputy chairs of the geographic working groups and the chairs of the thematic working groups automatically become members of APRRN's Steering Committee. At the biennial General Assembly meeting, the organisational members also elect the Chair and Deputy Chair of the Steering Committee from within their ranks for a two year term. A representative of the APRRN Secretariat's Thai host organisation has an ex officio position on the Steering Committee, if not already on the Committee in another capacity (APRRN Constitution 2014, art. 5(10)). ${ }^{9}$ Similarly, if the members thus far specified do not include a male and a female of refugee background, provision is made for individuals meeting the description to be appointed to a place on the Steering Committee (APRRN Constitution 2014, art. 5(9) $)^{10}$. The Steering Committee can also have up to three non-voting expert members appointed to it (APRRN Constitution 2014, art. 5(25)). The Steering Committee is responsible for the leadership and direction of the network as well as the periodic development of strategic plans. It is accountable to the General Assembly (APRRN Constitution 2014, art. 5).

APRRN also has a Secretariat in Bangkok which consists of the Executive Director, ${ }^{11}$ four other full-time paid staff, and volunteer interns (APRRN Secretariat, email, 26 August 2015). The Executive Director is appointed by and accountable to the Steering Committee (APRRN Constitution 2014, arts. 5(17) \& (18) and art. 7(1)). The APRRN Secretariat has many responsibilities, which include coordinating network activities; facilitating internal communication; managing external communication; providing support for the individual work of network members; representing the network at various fora; and obtaining funding for all of the foregoing (APRRN 2015a).

\footnotetext{
${ }^{8}$ If no one is elected as Chair or Deputy Chair of a Working Group, the Steering Committee has to power to make appointments to those positions (APRRN Constitution 2014, art. 5(23))

9 APRRN's compliance with Thai law relating to NGO registration is enabled by a Thai organisation acting as host for APRRN pursuant to a Memorandum of Understanding (APRRN 2013a, p. 5). Since late 2014, the host organisation has been the Institute of Human Rights and Peace Studies, Mahidol University (APRRN 2014b).

${ }^{10}$ At the time of writing, the Deputy Chair of APRRN was a man of refugee background. However, the position reserved for a woman of refugee background was vacant (APRRN 2015a).

${ }^{11}$ Prior to April 2014, the position title was 'Coordinator'. At the time of writing, the Executive Director position was vacant and the Program Manager was serving as the interim Executive Director.
} 
Since APRRN members do not pay membership fees, APRRN is reliant on donors to pay Secretariat staff and to carry out many of its activities. APRRN's income in in 2013 was 13,181,446.74 Thai Baht / USD 372,147 (APRRN 2014c, p. 30) and in 2014 was 10,980,675.69 Thai Baht / USD 310,013 (APRRN 2015b, p. 19) ${ }^{12}$. In other words, APRRN's access to funding is modest and possibly shrinking.

To date, APRRN's main donors have been Oak Foundation, Open Society Foundation, Planet Wheeler Foundation, Sasakawa Peace Foundation and UNHCR. APRRN's reliance on UNHCR funding is not ideal since UNHCR is also a major protection actor with its own agenda, which is not always aligned with APRRN's agenda. However, the fact that APRRN has a range of equally significant funding sources is probably an adequate safeguard against UNHCR or any other single donor having undue influence over the organisation.

At a minimum, donors require financial accountability. Unless APRRN is able to account properly to donors for the money it receives, potential donors will look after themselves by refusing to provide funding ${ }^{13}$. APRRN has recently started strengthening its financial accountability mechanisms. In 2015 the Steering Committee created a Finance SubCommittee, added a financial manager position to the Secretariat, and started to review and improve the network's accounting systems and methodology (APRRN Secretariat, email, 26 August 2015).

Although the governance arrangements described thus far are well-suited to ensuring accountability of APRRN to its organisational members and donors, they are not as wellsuited to ensuring the accountability of APRRN and its members to 'people in need of protection' or other stakeholders. In August 2014, APRRN's Steering Committee adopted a Code of Good Practice and a Code of Conduct, which go some distance towards ameliorating this accountability deficit. The Code of Good Practice sets out the responsibilities which the network has towards those with whom it engages. The Code of Conduct sets out expectations about the behaviour of individual APRRN members, staff and others when representing or working with APRRN.

\footnotetext{
${ }^{12}$ APRRN has not published its financial statements for years prior to 2013.

${ }^{13}$ Drawing on Hirschman's concepts of voice and exit, Courville (2006, p. 276) characterizes the option of exit as being itself a powerful accountability tool.
} 
Civil society network structures do not all conform to the same model. Among other things, they vary greatly in their level of formalisation. At one extreme are networks which have no leadership and no rules; at the other are networks which are so centralised in decision making authority and so rule bound that they verge on being unitary organisations (Anheier \& Themudo 2002; Fogarty 2011). From its inception APRRN fell somewhere between the two extremes and, following the trajectory of many other networks (Fogarty 2011; Ashman \& Sugawara 2013), has incrementally increased the formalisation of its governance arrangements over time in response to various challenges it has faced. In theory, the kind of bureaucratisation I have described makes for greater network longevity and stability than more informal ways of operating (Jordan \& Van Tuijl 2000; Diani 2011; Fogarty 2011). However, in a network that is designed to be member-led, the proper functioning of the governance infrastructure is heavily reliant on member engagement. Engaged membership of a network costs members time, if nothing else. Member engagement will only occur to the extent that the benefits of engagement are greater than the costs and are also greater than the benefits which can be achieved through a different investment of the same resources (Lake \& Wong 2009, p. 130). Unfortunately, not many APRRN members have found that their individual calculation works out in favour of engaging in network governance. APRRN has struggled to get people to volunteer for formal leadership positions. In practice, therefore, the continued operation of the network has depended on a fairly small subset of members and on the paid staff of the Secretariat.

\section{APRRN's Agenda Setting Ambitions}

One of APRRN's current ambitions is to be a regional agenda setter. In August 2012, at a workshop held as part of APRRN's fourth full membership meeting, it was pointed out that states, through the Bali Process, were pursuing a vision of regional cooperation, which focused on border control and gave short shrift to refugee protection. The proposition was put that APRRN could better advance refugee rights in the region by developing its own regional protection agenda and building a constituency for it, rather than by simply reacting to an agenda set by states (APRRN 2012, pp. 12-13). The proposition was endorsed by the APRRN General Assembly. In late 2012, a sub-Committee of the Steering Committee started developing a detailed Vision for Regional Protection in consultation with the APRRN membership (APRRN 2014c, p. 17). A wider consultation process was formally launched at the UNHCR-NGO Consultation in Geneva in mid-June 2013, with refugee representatives, 
other CSOs, and relevant inter-governmental agencies being invited to provide comment on the first draft of the Vision (APRRN 2014c, p. 18). At a side meeting at the UNHCR-NGO Consultations in June 2014, APRRN launched the second draft of its Vision and invited comment.

The first draft of the Vision states that APRRN envisages a region in which:

all refugees, asylum seekers, stateless persons and Internally Displaced People (IDPs) have equal and adequate access to assistance, protection and timely durable solutions as owed, and governments, non-governmental and intergovernmental agencies engaged in regional protection efforts collaborate effectively towards this common purpose with respect for their respective strengths and their differentiated roles and responsibilities.

The draft is about 1900 words in length because it goes on to elaborate every element of the foregoing paragraph in great detail. The second draft of the Vision has much in common with the first. The structure is basically unchanged between the drafts and much of the content remains the same. However, the second draft is about 2800 words in length because it sets out a longer list of things desired from a broader array of actors and does so in more detail than the first draft. The second draft also defines people in need of protection far more expansively than the first ${ }^{14}$. This enlarging of the Vision's scope is, of course, what one would expect to happen as more people with different views and priorities were given an opportunity to have a say (Wong 2012, p. 179).

I think that the development of the Vision for Regional Protection was probably a useful exercise in internal agenda setting because there is now a statement agreed to by a very large and diverse membership, setting out the details of the future they are committed to achieving together. This is a safeguard against the APRRN membership fracturing over disagreements about such matters in the future. On the other hand, the huge scope of the Vision means that it cannot all be achieved at once so there is still plenty of room for APPRN's membership to fracture over disagreements about which aspects to prioritise when allocating the network's limited resources.

\footnotetext{
${ }^{14}$ The very wide definition of people in need of protection has also been incorporated into APRRN's current strategic plan. See footnote 2 above.
} 
Quite separate from the question of the internal usefulness of the Vision, is the question of whether the statement in its entirety is a suitable engagement tool for APRRN to continue to use in attempting to influence the agenda of external actors. I am not convinced that it is. Studies of past successes and failures of transnational advocacy networks suggest that success is more likely when external agenda setting efforts are narrowly focused than when they are not. A salient illustration of this point is provided by Shawki's (2011) comparative case study of two transnational advocacy networks: the International Coalition to Ban Landmines (ICBL) and the International Action Network on Small Arms (IANSA). ICBL was formed in 1992. It pursued one goal only: a comprehensive ban on all antipersonnel mines. Five years of campaigning later, states adopted the Mine Ban Treaty ${ }^{15}$. In contrast, IANSA, which was formally launched in 1999, has tried to set the agenda on a whole host of issues at once but has not made much head way in doing so with any of them.

\section{APRRN's Activities}

I turn now to a consideration of whether, external agenda setting efforts aside, APRRN is advancing its mission through the activities it describes as core pillars.

\section{Outreach and sharing of knowledge and resources}

The first of APRRN's core pillars is 'outreach and sharing of knowledge and resources'. Since APRRN's members are geographically dispersed, much of the knowledge and resource sharing between members happens through virtual rather than face-to-face interaction. From the outset APRRN made use of Google group email lists for communication with and between members. APRRN's Working Groups are now using Webex to have regular meetings. APRRN has a public website that it uses for the dual purposes of disseminating information to members and others and increasing the network’s external visibility ${ }^{16}$. It also uses bimonthly e-newsletters, Facebook (https://www.facebook.com/APRefugeeRightsN), and Twitter (@APRRN_) as tools to engage members and non-members simultaneously (APRRN 2013a, p. 5).

\footnotetext{
${ }^{15}$ The Convention on the Prohibition of the Use, Stockpiling, Production and Transfer of Anti-Personnel Mines and on Their Destruction was adopted in 1997 and entered into force on 1 March 1999.

${ }^{16}$ In 2013 APRRN added a blog to which members were invited to contribute and in 2014 it added a Wiki which registered users can access. However, neither of these platforms has caught on with the APRRN membership to date.
} 
APRRN has been proactive in building its membership, with good reason. The more members a network organisation can claim, the bigger the constituency it can claim and hence the more external credibility and influence it is likely to have (Courville 2006, p. 276). Given that, at the time that APRRN started up, refugee issues were not even a blip on the radar of most regional CSOs (Harrell-Bond 2008, p. 13), including organisations with a primary focus in areas other than refugee rights in APRRN's membership has been a good way of building a constituency for refugee rights in the region in both appearance and fact. For the purpose of regional constituency building, geographic reach is also important. There are many countries that remain unrepresented or under-represented in APRRN's membership ${ }^{17}$. Building membership in unrepresented and under-represented countries is, therefore, part of APRRN's strategic plan.

The other purpose of building membership is to enlarge the knowledge and other resources available to the network as a whole. There are huge disparities in the resourcing, political influence and other capabilities of the different organisations presently making up the network. Nevertheless, every member can add some value to the network in terms of contacts, ideas, expertise, perspectives, skills, etc. Whether all members do add the value that they potentially can add is a different matter. My overall impression, gleaned through monitoring day-to-day interaction on various APRRN email lists and paying attention to information about which members have participated in which APRRN activities, is that not all of the organisations that are nominally members of the network are substantially engaged with network activities on an ongoing basis. For example, some NGOs became members of APRRN in 2012 as a result of active outreach by the network (APRRN 2013a, p. 5), but I have not noticed them participating in email lists or other network activities since.

As well as building its own membership, APRRN has built working relationships with other civil society networks with related missions. APRRN began its existence with strong sponsorship and support from two other civil society networks: the Southern Refugee Legal Aid Network (SRLAN) (Harrell-Bond 2008) and the IDC. The three networks coordinate their activities and support each other in various ways (Taylor 2013). Other civil society

\footnotetext{
${ }^{17}$ For example, there is only one member organisation in Iran, though Iran hosted, that is, provided refuge for, 25 per cent of the Asia Pacific population of asylum seekers and refugees at the end of 2014 (UNHCR 2015b, Table 1).
} 
networks with which APRRN has strong engagement include the International Council of Voluntary Agencies (ICVA) ${ }^{18}$ and the Solidarity for Asian People’s Assembly (Taylor 2013).

As with building membership, building alliances serves the purpose of getting a wider and wider constituency on-side with APRRN's mission and potentially enlarges the pool of resources to which it has access. However, multiplying alliances also comes with costs. The more relationships an organisation is involved in the greater the risk that the relationships will sit uncomfortably with each other (Jordan \& Van Tuijl 2000, p. 2063). For example, the alliances in which an organisation is involved may have visions that are broadly congruent with its own but may have contradictory strategies for getting there. Even if an organisation's alliances are in complete harmony, active participation in alliances necessarily uses up resources some of which could perhaps be put to better use.

A point worth making at this juncture is that, just as APRRN has multiple alliances, many of APRRN's members are also members of one or more of APRRN's other members and members of other CSOs besides. In fact, the relationships fostered through mutual engagement in APRRN activities have resulted in the formation of new national networks of APRRN members in Indonesia (SUAKA), Nepal (Refugee Lawyers Network) and Pakistan (the Consortium for the Protection of Refugees Rights in Pakistan) (APRRN 2014c, pp. 8 \& 17; Jones, Mayerhofer \& Testa 2015, pp. 32-39). The existence of this very dense set of cross-relationships can create synergies for those involved. However, they also have the potential to create opposite effects. Involvement in multiple overlapping alliances can simply dissipate the energy of key players for no particular gain. For example, a proposal to establish a regional network focused on statelessness has come out of a workshop co-organised by APRRN and APRRN is involved in further development of it. ${ }^{19}$. However, the organisations interested in becoming members of the new network are likely to overlap considerably with the membership of APRRN's statelessness working group. That is one more network's meetings for all of them to attend, probably at the expense of more productive activities. The most sensible way forward may be for APRRN to leave statelessness issues to the new network and take the opportunity to narrow its own agenda to a more manageable size.

\footnotetext{
${ }^{18}$ APRRN is a member of ICVA and, since March 2015, has been on ICVA's Board (ICVA 2015a). Since 2013, ICVA's Asian Hub - a two person team - has been hosted by APRRN's Secretariat office in Bangkok (ICVA 2015b).

${ }^{19}$ Civil Society Retreat on Resolving Statelessness in Asia and the Pacific Co-hosted in Bangkok on 15-16 June 2015 by UNHCR, the Asia Pacific Refugee Rights Network (APRRN) and the Institute of Human Rights and Peace Studies of Mahidol University
} 


\section{Mutual capacity strengthening}

The second of APRRN's 'core pillars' is 'mutual capacity strengthening'; this mostly takes the form of organising training and workshops for members often delivered by other members. APRRN has organised legal aid training in partnership with SRLAN, alternatives to immigration detention workshops and training in partnership with IDC, as well as refugee mental health training, short courses on refugee law, and so on. These capacity strengthening activities have a short to medium term pay off for members which is likely in the longer term to translate into a payoff for people in need of protection. It does not matter how good the intentions of CSOs are, they need to have appropriate knowledge and skills in order to be of any use to those they purport to serve.

More ambitiously, in 2012, APRRN conducted a pilot study of the coping strategies of urban refugees in Bangkok, Kuala Lumpur, Kathmandu, and New Delhi. The study was conducted in collaboration with APRRN members in the countries concerned (APRRN 2013b). Part of the study methodology involved interviewing refugees and asylum seekers across the four countries. Follow up national consultations have since been held in India, Indonesia, Thailand and Nepal between APRRN members organisations and refugee communities with the aim of ascertaining how the former can better support the latter (APRRN 2014d, p. 9). This project is a good demonstration of APRRN functioning as a vehicle through which members are able to achieve far more together than they could by working individually.

\section{Joint Advocacy}

The third of APRRN's core pillars is 'joint advocacy’. From its establishment to November 2015, APRRN had issued 35 statements on various protection issues arising at a national or regional level. In one case, the statement was issued as part of wider advocacy strategy and used to good effect in influencing a relevant target audience (Taylor 2013). In most cases though, APRRN seems not to have done much beyond issuing the statement, thus appearing to run the risk of the statement having little impact. On the other hand, a statement is usually initiated by an APRRN member with a particular interest in an issue so it may well be that the member seeking the statement has had a strategy in place for its use.

Statements aside, APRRN's advocacy activities are usually directed at the particular target audiences that need to be influenced in order to achieve the desired outcome. There are a number of intergovernmental entities that APRRN attempts to influence working both on its 
own and through alliances. The most important of APRRN's advocacy targets is UNHCR. As part of working with ICVA ${ }^{20}$, APRRN has, since 2009, taken responsibility for drafting the Asia Pacific NGO statement for the UNHCR governing body meetings. APRRN also participates in the annual UNHCR-NGO Consultations ${ }^{21}$ and by invitation in various UNHCR-initiated high-level meetings and dialogues. One valuable role the Secretariat plays in advance of and during such gathering is that of facilitating coordination between APRRN members attending in order to maximise individual and collective impact. Beyond this, APRRN engages in correspondence and dialogue with key UNHCR officers frequently and on a variety of issues. The problem is that UNHCR and other intergovernmental entities are subject to many countervailing and generally much more powerful sources of influence. If APRRN dissipates its limited resources trying to influence multiple intergovernmental entities in relation to multiple issues all at the same time, it may not get far with any of them.

Last but not least, APRRN works to achieve national policy reform through supporting members in their advocacy work with individual governments. This kind of advocacy work involves attempting to achieve a very specific goal by very precisely identifying the target audiences best able to assist in the endeavour and then carefully choosing the advocacy tactics most likely to succeed with those audiences. APRRN claims to have helped members in a number of countries advance their national policy reform agendas by working with them in this way (APRRN 2013a, p. 5; APRRN 2014c, p. 9). For example, throughout the seven years since APRRN's establishment, APRRN and IDC have been working together to promote alternatives to immigration detention (APRRN \& IDC 2014, p. 3). Among other things, they have organised a series of National Roundtable discussions on alternatives to detention that have brought together civil society actors and government officials in a number of regional countries (Institute of Human Rights and Peace Studies 2015). These Roundtable discussions are preceded by strategic planning meetings between the civil society actors, as well as discussions with allies such as UNHCR and national human rights institutions (IDC 2014). A National Roundtable discussion held in Indonesia on 23 February 2015 resulted in a commitment to continue meeting regularly with a view to collaborating on limiting the detention of children (IDC 2015). A National Roundtable discussion held in Thailand on 25 February 2015 resulted in agreement that government and civil society would continue to

\footnotetext{
${ }^{20}$ ICVA coordinates the NGO Statements delivered at EXCOM and Standing Committee meetings and co-hosts the annual UNHCR-NGO Consultations.

${ }^{21}$ The Executive Director of APRRN's Secretariat was the Rapporteur for the Consultation in 2012 (APRRN 2013a, p. 6).
} 
work together to change law and policies relating to immigration detention and to ensure implementation of the changes in practice (Institute of Human Rights and Peace Studies 2015). These are not policy reform successes, of course, but they are steps towards success. As Jones, Mayerhofer and Testa (2015, pp. 4-5) observe, when change is achieved it is 'often the result of cumulative efforts by multiple actors’ over many years.

\section{Concluding Reflections}

This special issue of Cosmopolitan Civil Societies had its genesis in a workshop convened to explore the impacts of Australian policies on asylum seekers and refugees, governments and civil society in the region. However, states are not the only actors that matter. APRRN is a civil society network organisation which works to advance the rights of people in need of protection in the Asia Pacific region. Notwithstanding the negative impact of Australian asylum seeker policy, APRRN has made some progress towards achieving its mission and has the potential to continue doing so. What I have argued in this article is that the realisation of this potential is not a foregone conclusion.

The resources which APRRN has available to deploy in pursuit of its mission are primarily those made available to it by its donors and its members. As I have explained above, APRRN's donor funding is modest and does not appear to be on a growth trajectory. APRRN's membership is growing, but such growth does not of itself increase the resources available to the network. What matters is member engagement and as I have also explained above, the level of member engagement in internal governance is less than is necessary and in network activities is variable.

The danger is that APPRN's supporting infrastructure will soon become, if it is not already, unequal to bearing the weight of its internal agenda and its external agenda setting ambitions, both of which have been growing in tandem with its membership. Therefore, instead of further building membership (or, for that matter, alliances which also come with costs attached), it may be better for APRRN to focus in the first instance on another goal in its strategic plan - that of building stronger working relationships between existing members. The stronger the working relationships within the network, the more benefit individual members are likely to receive from engagement with the network and therefore the more likely they are to engage, creating a virtuous cycle. 
APRRN's working groups facilitate the building of strong working relationships as they provide vehicles through which members with similar thematic or geographic interests can cooperate with each other. However, experience over seven years has demonstrated that the existence of the working groups is not enough. The question is what more might be enough?

At the time of launching the first draft of its Vision, APRRN foreshadowed that it would start developing a Plan of Action to achieve the Vision as well as a Research and Consultation Framework (APRRN 2014c, p. 18). The three documents together were intended to constitute APRRN's Regional Protection Framework and to be living documents. There was further engagement with the APRRN membership in relation to these documents at the full membership meeting in September 2014 but there has been not much movement since. In her study of the Platform of European Social NGOs, which has a similar structure to APRRN, Cullen (2015) found, confirming previous studies of other networks, that working together on living documents which focused on what the network was for (rather than what it was against) played a significant role in bringing members 'closer together'. Such findings suggest that renewing work on APRRN's Regional Protection Framework may make a contribution toward building stronger working relationships between APRRN members. That said, APRRN's Vision is so all-encompassing that developing a single Plan of Action upfront to achieve all of it would seem neither feasible nor useful. What seems more feasible and useful is for APRRN members to agree on one specific part of the Vision to achieve first and then focus on developing a plan of action to achieve just that part, or for different working groups to each mobilize around developing a plan of action to achieve the part of the Vision of greatest importance to them. It is worth emphasising that 'more feasible' does not mean easy. As observed above, the size and diversity of APRRN's existing membership militates against easily achieving agreement on priorities and strategies. Nevertheless, as long as APRRN lacks the resources to do everything it would like to do, it has no choice but to prioritise and, if it wishes to maximise its effectiveness, to do so in a more ruthlessly disciplined fashion than hitherto. In sum, APRRN is presently experiencing growing pains but if it responds appropriately it is likely to come through them in a state healthy enough to survive and be successful.

I would, of course, be on unsafe ground if I purported to draw generalised conclusions about transnational civil society networks on the basis of a case study of one such network. It is 
possible, though, to make some observations about the extent to which this case study confirms or disconfirms findings made by previous studies of other transnational civil society networks. In fact, my study tends to confirm findings made in previous studies. A study by Ashman and Sugawara (2013) found that network organisations that are large (twenty six or more members) or are pursuing complex shared purposes over the long term tend to have a complex structure. The APRRN case bears this out. Ashman and Sugawara (2013) also found that the complexity of shared purposes tends to grow with age. Again the APRRN case, especially the development of APRRN's Vision for Regional Protection starting in 2012, bears this out.

Ashman and Sugawara (2013) classify networks that have lasted six years or more as 'old' because many networks fail within the first five years. The fact that APRRN has survived to the age of seven years and has made progress in achieving its mission confirms previous studies that have found that networks that are successful in both surviving and pursuing their mission tend to be those that are more bureaucratized (Fogarty 2011; Davy 2013, p. 107). However, bureaucratisation alone is not enough. As previous studies have found, networks pursuing complex shared purposes need a high level of member commitment to succeed, but, given competing demands on member resources, cannot take such commitment for granted (Yanacopulos 2005; Davy 2013, pp. 98-99). APRRN's difficulties eliciting a level of member commitment commensurate with the scale of its ambitions bears this out. The lesson for CSOs contemplating the creation of a network organisation as a vehicle for joint action is that they need to make careful choices about internal governance from the outset in order to maximise their chances of success. The lesson for existing civil society network organisations is that they need continuously to monitor whether their ambitions are outstripping their organisational strength and, if so, to take corrective action.

\section{Acknowledgements}

This article was written while I was an Academic Visitor at the Melbourne Social Equity Institute, University of Melbourne and a Visiting Fellow at the Development Policy Centre, Australian National University. I would like to thank Tamara Domicelj, Julia Mayerhofer, and the two anonymous reviewers for their comments on previous versions of this article. All views and errors are, of course, mine alone. 


\section{References}

Anheier, H. 2014, 'Civil Society Research: Ten Years on', Journal of Civil Society, vol. 10 no. 4, pp. 335-339, doi: http://dx.doi.org/10.1080/17448689.2014.984973

Anheier, H. \& Themudo, N. 2002, 'Organizational Forms of Global Civil Society: Implications of Going Global' in Glasius, M., Kaldor, M. and Anheier, H. (eds), Global Civil Society 2002, Oxford University Press, Oxford, pp. 191-216

Asia Pacific Refugee Rights Network 2009, Asia Pacific Consultation on Refugee Rights 2, Accessed 21 October 2015, http://www.aprrn.info/1/pdf/FINAL_APCRR2_Report.pdf

APRRN 2012, Fourth Asia Pacific Consultation on Refugee Rights, Accessed 21 October 2015, http://aprrn.info/apcrr4-report/

APRRN 2013a, Annual Report 2012, Accessed 21 October 2015, http://aprrn.info/annual-report-2012/

APRRN 2013b, Urban Refugees in Asia Pacific: Resiliency and Coping Strategies Pilot Study Report, Accessed 21 October 2015, http://aprrn.info/report-on-the-urban-refugees-in-asia-pacificresiliency-and-coping-strategies-national-consultations-bangkok/

APRRN 2014a, Strategic Plan 2014-2018, Accessed 21 October 2015, http://aprrn.info/wpcontent/uploads/2015/10/APRRN_Strategic_Plan_2014.pdf

APRRN 2014b, December 2014 Newsletter, Accessed 21 October 2015, http://aprrn.info/aprrndecember-2014-newsletter/

APRRN 2014c, Annual Report 2013, Accessed 21 October 2015, http://aprrn.info/annual-report-2013/

APRRN 2014d, Report on the 5th Asia Pacific Consultation on Refugee Rights, Accessed 30 September 2015, http://www.aprrn.info/1/index.php/resources/publications-andmaterials/reports/299-apcrr5-report

APRRN 2015a, About Us: Structure, Accessed 21 October 2015, http://aprrn.info/about-us/structure/

APRRN 2015b, Annual Report 2014, Accessed 31 October 2015, http://aprrn.info/wpcontent/uploads/2015/10/Annual-Report-2014-Final.pdf

APRRN and International Detention Coalition 2014, Strengthening Capacity to Implement Alternatives to Detention, Kuala Lumpur, Malaysia, May 2014, Workshop Report, Accessed 8 February 2016, http://idcoalition.org/wp-content/uploads/2014/05/Workshop-ReportFINAL.pdf

APRRN Constitution 2014, Accessed 31 October 2015, http://aprrn.info/wpcontent/uploads/2015/10/APRRN-Constitution-2014-final.pdf

Ashman, D. \& Sugawara, C. 2013, 'Civil society networks: Options for network design', Nonprofit Management \& Leadership, vol. 23, no. 3, pp. 389-406, doi:

http://dx.doi.org/10.1002/nml.21062

Center for Victims of Torture 2004, New Tactics in Human Rights: A Resource for Practitioners, Accessed 30 September 2015, https://www.newtactics.org/sites/default/files/resources/entirebook-EN.pdf

Coalition 2013, The Coalition's Policy for a Regional Deterrence Framework to Combat People Smuggling, Accessed 7 February 2016, http://lpaweb-static.s3.amazonaws.com/13-0823\%20The\%20Coalition\%E2\%80\%99s\%20Policy\%20for\%20a\%20Regional\%20Deterrence\% 20Framework\%20to\%20Combat\%20People\%20Smuggling.pdf

Courville, S. 2006, 'Understanding NGO-based social and environmental regulatory systems: Why we need new modes of accountability' in Dowdle, M. (ed.), Public Accountability: Designs, Dilemmas and Experiences, Cambridge University Press, Cambridge, pp. 271-300

Cullen, P. 2015, 'European Union non-governmental organizational coalitions as professional social movement communities’, Journal of Civil Society, vol. 11, no. 2, pp. 204-225, doi: http://dx.doi.org/10.1080/17448689.2015.1052228 
Davy, D. 2013, 'Measuring the immeasurable: Understanding the effectiveness of anti-child trafficking transnational advocacy networks’, Cosmopolitan Civil Societies, vol. 5, no. 2, pp. 84-113, doi: http://dx.doi.org/10.5130/ccs.v5i2.3102 .

Diani, M. 2011, 'Social movements and collective action' in Scott, J. and Carrington, P. (eds), The Sage Handbook of Social Network Analysis, Sage Publications, London, pp. 223-235

Fogarty, E. A. 2011, 'Nothing succeeds like access? NGO strategies towards multilateral institutions', Journal of Civil Society, vol. 7, no. 2, pp. 207-227, doi: http://dx.doi.org/10.1080/17448689.2011.573670

Godsäter, A. 2015, 'Civil society and regional governance: Knowledge production and issue-framing around SADC’, Journal of Civil Society, vol. 11, no. 1, pp. 100-116, doi: http://dx.doi.org/10.1080/17448689.2015.1024948

Harrell-Bond, B. 2008, 'Building the infrastructure for the observance of refugee rights in the Global South', Refuge, vol. 25, no. 2, pp. 12-28

Heyman, J. 2011, 'An academic in an activist coalition: Recognizing and bridging role conflicts', Annals of Anthropological Practice, vol. 35, pp. 136-153, doi: http://dx.doi.org/10.1111/j.2153-9588.2011.01086.x

International Council of Voluntary Agencies 2015a, Governance, Accessed 30 September 2015, https://icvanetwork.org/governance

ICVA 2015b, Asian Region, Accessed 30 September 2015, https://icvanetwork.org/asia-region

International Detention Coalition 2008, International Detention Monitor, Issue 1, Accessed 13 August 2015, http://idcoalition.org/wp-content/uploads/2009/05/international_detention_monitor_.pdf

IDC 2014, 'IDC, APRRN and SUAKA national planning in Jakarta', News, 2 September, Accessed 8 February 2016, http://idcoalition.org/news/idc-apprn-suaka-national-planning-jakarta/

IDC 2015, 'Indonesia Roundtable on Child Detention', News, 12 March 2015, Accessed 8 February 2016, http://idcoalition.org/news/indonesia-roundtable-on-child-detention/

Institute of Human Rights and Peace Studies, Mahidol University 2015, 'IHRP collaborates with human rights organizations to end immigration detention of children in Thailand', Latest News, Accessed 8 February 2016, http://www.ihrp.mahidol.ac.th/index.php/en/archive/10-lastestnews/140-ihrp-collaborates-with-human-rights-organizations-to-end-immigration-detention-ofchildren-in-thailand

Jones, E., Mayerhofer, J. \& Testa, A. 2015, Positive Practices in Refugee Protection in the AsiaPacific Region Research Report, APRRN, Bangkok, Accessed 6 February 2016, http://www.alnap.org/pool/files/positivepracticesasiapacific.pdf

Jordan, L. \& Van Tuijl, P. 2000, 'Political responsibility in transnational NGO advocacy' World Development, vol. 28, no. 12, pp. 2051-2065, doi: http://dx.doi.org/10.1016/S0305750X(00)00078-4

Katz, H. \& Anheier, H. 2005, 'Global connectedness: The structure of transnational NGO networks' in Anheier, H., Kaldor, M. and Glasius, M. (eds), Global Civil Society 2005/6, Sage Publications, London, pp. 240-265

Labaree, R. 2002, 'The risk of "Going Observationalist”: Negotiating the hidden dilemmas of being an insider participant observer’, Qualitative Research, vol. 2, no. 1, pp. 97-122, doi: http://dx.doi.org/10.1177/1468794102002001641

Lake, D.A \& Wong, W.H. 2009, 'The politics of networks: Interests, power, and human rights norms' in Kahler, M. (ed.), Networked Politics: Agency, Power, and Governance, Cornell University Press, Ithaca, pp. 127-150

Lichterman, P. 1998, 'What do movements mean? The value of participant-observation', Qualitative Sociology, vol. 21, no. 4, pp. 401-418, doi: http://dx.doi.org/10.1023/A:1023380326563 
Murdie, A. 2014, 'Scrambling for contact: The determinants of inter-NGO cooperation in non-western countries', Review of International Organizations, vol. 9, pp. 309-331, doi: http://dx.doi.org/10.1007/s11558-013-9180-2

Nash, C. 2014, 'Networking for change: The Development of the European Network on Statelessness and perspectives on developing other regional and global statelessness coalitions', Tilburg Law Review, vol. 19, pp. 212-222, doi: http://dx.doi.org/10.1163/22112596-01902021

Pulido, L. 2008, 'FAQs: Frequently (Un)Asked Questions about being a scholar activist' in Hale, C. (ed.), Engaging Contradictions: Theory, Politics and Methods of Activist Scholarship, University of California Press, Berkley, pp. 341 - 366

Shawki, N. 2011, 'Organizational structure and strength and transnational campaign outcomes: A comparison of two transnational advocacy networks', Global Networks, vol. 11, no. 1, pp. 97117, doi: http://dx.doi.org/10.1111/j.1471-0374.2011.00309.x

Steen-Johnsen, K. Eynaud, P. \& Wijkström, F. 2011, 'On civil society governance: An emergent research field’, Voluntas, vol. 22, pp. 555-565, doi: http://dx.doi.org/10.1007/s11266-0119211-7

Taylor, S. 2013. 'Civil society and the fight for refugee rights in the asia pacific region' in Francis, A. and Maguire, R. (eds), Protection of Refugees and Displaced Persons in the Asia Pacific Region, Ashgate, Farnham, Surrey, pp. 35-52

Uldam, J. \& McCurdy, P. 2013, 'Studying social movements: Challenges and opportunities for participant observation', Sociology Compass, vol. 7, no. 11, pp. 941-951, doi: http://dx.doi.org/10.1111/soc4.12081

UNHCR 2015a, Where We Work: Asia and the Pacific, Accessed 13 August 2015, doi: http://www.unhcr.org/pages/4a02d8ec6.html

UNHCR 2015b, Global Trends 2014, UNHCR, Geneva

UNHCR 2015c, UNHCR Global Report 2014, UNHCR, Geneva

Wong, W.H 2012, Internal Affairs: How the Structure of NGOs Transforms Human Rights, Cornell University Press, Ithaca

Yanacopulos, H. 2005, 'The strategies that bind: NGO coalitions and their influence', Global Networks, vol. 5, no. 1, pp. 93-110, doi: http://dx.doi.org/10.1111/j.1471-0374.2005.00109.x 